feathers and covered with a black, hard, thick skin, overlapped in part by the lengthened frontal plumes. Another, a male from Camorta island, is similar; but the frontal plumes being shorter, the naked callosity is more evident. In a third, a female from Nangcowry island, the naked area extends almost from the forehead to low down the nape. At the anterior edge of the naked skin is a large fold, the true nature of which it is difficult to ascertain in the dry specimen.

\title{
On the Structure of the Caudal Appendage of some Ascidian Larva.
} By M. A. Giard.

We know, from the brilliant discovery of M. Lacaze-Duthiers, that certain species of the genus Molgula issue from the egg in an amœboid form, having no external resemblance to the larvæ of the other Ascidia. Kupffer soon extended this discovery to several other types of the same genus. Hancock, on the other hand, has shown that this exceptional mode of evolution does not occur generally in all the species of the group Molgulidæ. Thus Molgula complanata and $M$. ampulloides have a urodelous larva furnished with a welldeveloped caudal appendage. I have also indicated some analogous cases, and called the attention of zoologists to the interesting fact that the Molgulce with abnormal embryos are free in the adult state, whilst the regularly constructed larvæ belong to species which become permanently fixed.

The investigation of a species of Molgula which is very common on the shores of the Boulonnais enables me now to enunciate this law with more certainty, and furnishes a new example of a very singular peculiarity of structure which I had previously observed in the caudal appendage of the larvæ of the genus Cynthia.

The rich shores of Wimereux and Portel, to the east and west of Boulogne, are literally carpeted, in the first part of the laminarian zone, by a fine Molgula which, instead of living isolated like its congeners, occurs in gregarious masses of individuals adhering firmly to each other, and often even rendered polyhedral by mutual pressure. From this mode of life this species might be supposed to be the one described by J. Alder under the name of Molgula socialis (Ann. \& Mag. Nat. Hist. March 1863, p. 159); but the anatomical characters given by the English naturalist are not sufficient to establish their identity. He does not mention the length of the siphons, which is very remarkable; the size (half an inch) is less than that of the Wimereux specimens, which average two to three centimetres in height; lastly, the only specimen of the above species examined by Alder was a colony attached to a Pecten maximus dredged at twelve miles from Hastings. Now the Molgula of the Boulonnais is no longer abundant in deep water, where it is replaced by the twisted masses formed by the tubes of the Hermella.

The Wimereux Molgula often establishes itself on the lower surface of stones, but more frequently on the upper surface of the Jurassic rocks (Portland sandstones) which constitute the sea--bottom. The 
form varies according to the position which they occupy in the masses: the individuals placed in the centre become elongated, in order that they may not be covered up by their neighbours; frequently there is even developed at the side opposite the siphons a peduncle, which may attain a length of two centimetres.

As might be foreseen, this Ascidian, being fixed, produces a urodelous larva, the caudal appendage of which even attains a considerable development. The terminal portion of the tail presents rays of firmer texture than the rest of the membrane, which I cannot better compare to any thing than the natatory rays of the embryos of fishes.

But this arrangement is not strongly marked in the larva of our Molgula; and I have only cited this species in the first place because it seemed to me remarkable to find in the same genus, side by side with anurous larvæ, others presenting a caudal appendage so highly organized.

A much higher degree of complication is observed in the embryos of certain Cynthice, and especially in the species belonging to the group Styela of Savigny. I have more particularly investigated a little Ascidian (4-6 millims. in height), the anatomical structure of which closely approaches that of Styela, but which, in accordance with the antiquated and perfectly artificial nomenclature still adopted in recent works on the Ascidia, must be placed in a very different group. In fact this species, which I shall call Polystyela Lemirri, is a composite, or at least a social, Ascidian. The individuals (blastozoïtes) forming each colony (cormus) are arranged upon a common basal lamina, like the coral-polyps of the genus Sympodium. Polystyela approaches the Synascidia by other morphological and even by physiological characters: the embryos issue fully formed from the maternal organism, within which the incubation has been effected.

The caudal appendage of the embryo of Polystyela presents throughout its length perfectly developed and very regularly arranged rays. These rays, which are perpendicular to the dorsal cord in the first part of the tail, become gradually more inclined towards the axis in proportion as they approach the extremity. This extremity itself also surprisingly resembles that of a young fish; a drawing representing it could hardly be distinguished from that which might be made of the embryo of Macropodus viridis ornatus, for example.

In the first portion of the tail, and nearly to the posterior third of the dorsal cord, the natatory rays, which are very slightly inclined to this cord, present a cartilaginous base of granular aspect, occupying about one third of the membranous limb of the appendage. We have consequently at this point a structure nearly identical with that which is observed in the caudal appendage of the young salmon about the tenth day of its development, namely cartilaginous supports resting or not resting upon the cord, and terminated by rays sustaining a delicate membrane. I content myself at present by indicating these curious facts, proposing some day to revert to the signification which may be ascribed to them.-Comptes Rendus, June 29, 1874, pp. 1860-1863. 


\section{Parthenogenesis in Ferns.}

An interesting paper by Dr. William G. Farlow, late Assistant in the Botanical Department at Harvard University, and at the time a student in the laboratory of Professor De Bary, of Strasburg, entitled "An asexual growth from the Prothallus of Pteris serrulata,"was read in January last at a meeting of the American Academy of Arts and Sciences, and is just printed in its 'Proceedings.' A fern, as is well known, comes to fructification and produces spores without any fertilization. The spores in germinating produce a liverwort-like structure, the prothallus, on which the two kinds of sexual organs are developed; the fertilization of a cell in the one by a spermatozoid from the other results in the development and growth of the former into a bud, and so into a fern-plant. Now Dr. Farlow has discovered, in a sowing of the spores of the common Pteris serrulata, prothalli which were developing fern-plantlets from their substance quite apart from any archegonium, starting in a different way by a direct outgrowth from the prothallus, beginning with a scalariform duct, but producing plantlets thus far undistinguishable from those which arise from an archegonium through fertilization. The paper is illustrated by figures, which show the earlier stages and the difference between this asexual outgrowth and the ordinary development.

Dr. Farlow, confining himself strictly to the facts of the case and their direct interpretation, does not use the word parthenogenesis. But the case seems to be substantially analogous to that of parthenogenesis in phænogamous plants, the few cases of which that have been probably, if not unequivocally, made out are much fortified by the present discovery. If it be demurred that the case is one of budgrowth and therefore not of the nature of parthenogenesis proper, the reply is that it comes from a parthenogenetic spore, which here develops plants without the sexual fertilization of that class of plants. The conclusion, if the facts hold good, is that sexual fertilization, however necessary, is not absolutely necessary in every generation of plants, somewhat as cross-fertilization, however necessary in the long run, is generally unnecessary in every generation; only the rule in the former is far more strict.-Asa GRAY in Silliman's American Journal, April 1874.

\section{On New-Zealand Whates.}

The Museum at Auckland has what Dr. Hector believes to be the fœtus or very young of Neobalana marginata; it is only $2 \frac{1}{4}$ feet in length, and has the baleen perfect. All the characters agree exactly with the previous and larger specimen of that whale. It was called a calf of a right whale, the old one being described as of an enormous size !

Dr. Haast has received a fresh and complete animal of Dotichodon, perhaps D. Layardi; and he has also an Epiodon, the skeleton of which agrees with Burmeister's Epiodon australis in every part but the sternum; and in that it only differs slightly. Is it different from E. chathamensis.-J. E. Gray. 


\section{$2 \mathrm{BHL}$ Biodiversity Heritage Library}

Giard, Alfred. 1874. "On the structure of the caudal appendage of some Ascidian larvæ." The Annals and magazine of natural history; zoology, botany, and geology 14, 164-166. https://doi.org/10.1080/00222937408680944.

View This Item Online: https://www.biodiversitylibrary.org/item/63340

DOI: https://doi.org/10.1080/00222937408680944

Permalink: https://www.biodiversitylibrary.org/partpdf/58739

\section{Holding Institution}

University of Toronto - Gerstein Science Information Centre

\section{Sponsored by}

University of Toronto

\section{Copyright \& Reuse}

Copyright Status: NOT_IN_COPYRIGHT

This document was created from content at the Biodiversity Heritage Library, the world's largest open access digital library for biodiversity literature and archives. Visit BHL at https://www.biodiversitylibrary.org. 